\title{
4. 'Failed' or resilient subaltern communities? Pacific indigenous social protection systems in a neoliberal world
}

\section{ABBSIRACII}

The notion of failed state is based on culturally, historically and ideologically slanted lenses and tends to rank post-colonial societies at the lower end of the Failed State Index (FSI). Likewise, the Social Protection Index (SPI) uses neoliberal and Western-based variables and tends to disadvantage subaltern post-colonial communities as in the Pacific. This article reverses this trend by arguing for a re-examination of the factors which shape the resilience and adaptability of local communities, something which has always been ignored by mainstream classificatory schemas such as the FSI and SPI. To this end, the article examines the indigenous and local human security and social protection systems in the Pacific and how these provide support mechanisms for community resilience and adaptation in the face of a predatory neoliberal onslaught and globalisation. It focuses on kinship, reciprocity, communal obligation and communal labour as examples of social protection mechanisms in four case studies-Fiji, Samoa, Kiribati and Vanuatu. Of significance here is the role of critical and progressive journalists and media in deconstructing the ideological and cultural bias embedded in these discourses.

Keywords: community, failed state, globalisation, indigenous, social protection, vulnerability

\section{STEVEN RATUVA}

\section{Macmillan Brown Centre for Pacific Research, University of Canterbury}



VER THE years Pacific Island societies have been framed with negative imageries such as 'arc of instability' (Ayson, 2007), 'failed states' (Wainwright, 2003) and the situation has even been described 
as the 'Africanisation of the Pacific' (Reilly, 2000) and 'barbed wire reality' (Dobell, 2007). Sadly, such degrading terms are not just used as political polemic in the media but have even been articulated in serious academic discourses and official policy thinking. Through the mainstream media's constant repetitive polemics and sensationalism, the unsavory images of Pacific island states as domains of corruption and instability have been crystalised in popular political discourse.

The notion that some states have failed or are failing has gained prominence in recent years and this has been reinforced by the creation of classificatory schemas such as the Failed States Index (FSI) developed by the Fund for Peace, World Bank's Governance Index (GI) and the Social Protection Index (SPI). Predictably, the Pacific Island states are ranked on the lower end of the global stratification because in most cases, the measuring variables used are culturally, historically and ideologically biased in favour of neoliberal and Western paradigms and tend to ignore the worldviews and unique cultural dispositions and historical realities of subaltern post-colonial communities. Under the guise of being 'scientific', these methodologies are underpinned by negative imageries and cultural stereotypes which are often used to construct assumptions about subaltern societies, an ontological process referred to by Edward Said as 'orientalism' (Said, 1977).

However, the use of alternative classificatory schemas such as the Happy Planet Index (HPI) introduced by the New Economic Foundation in 2006 reverses the trend with Pacific and many other post-colonial states ranked towards the top of the list. Thus the need to understand the dynamics of subaltern communities and their cultural institutions which provide them with resilience is important to counter some of the myths propagated by failed states proponents. The term failed state itself is subject to multiple interpretation. Noam Chomsky referred to the US as a 'failed state' because of its inability to live up to its claim to being democratic (Chomsky, 2006).

Although this article is not about FSI per se, I briefly refer to it here to illustrate how even in presumably progressive policy areas such as social protection, the focus of this article, similar culturally and ideologically biased variables are used in social analysis and stratification. The SPI is related to FSI in various ways including the assumption about the paramountcy of formal western governance and development systems and the subordinate status of informal, subsistence and non-capitalist norms and institutions. The article 
reverses this mainstream paradigm by focusing, not on formal and institutionbased social protection policies but on culture-based indigenous social protection systems used by subaltern Pacific communities as a means of building resilience and developing adaptation strategies. The major plank of the argument here is that far from being 'failed', Pacific communities have over the years developed culture-based mechanisms, not captured in Western-based classificatory schemas, which provide them with resilience and adaptability in the face of neoliberalism and globalisation.

It must be noted that social protection is part of the generic framework of human security. Human security, which encompasses an array of social, psychological, political and economic factors which shape people's sense of well-being, is often framed as a response to the increasing sense of insecurity and proliferation of new forms of security threats, which cannot be adequately captured by the confines of the mainstream, state-centric national security paradigm (McCormack, 2011). As a critical aspect of human security, social protection focuses on addressing the situation of vulnerable groups and individuals in society especially in times of social and economic difficulties. This makes it a central plank in today's policy drive towards combating poverty, social disempowerment and economic marginalisation (Devereux \& Cipryk, 2009; Kohler, Cali \& Stirbu, 2009).

In an attempt to highlight the often ignored locally-based social security mechanism of subaltern communities, this article examines some selected forms of indigenous social protection mechanisms in four Pacific communities namely Fiji, Samoa, Kiribati and Vanuatu and how they are used as social safety leverage to sustain and reproduce a semi-subsistence mode of existence. Some of this analysis could inform the way the media understands the reality of Pacific communities.

\section{The social protection debate}

Devereux and Sabates-Wheeler (2004) conceive of social protection as a complex social engineering process involving four aspects: preventive, protective, income-generating and transformative. With the proliferation of institutional stakeholders and funders - multilateral, bilateral and privatediverse ideological and policy positions in the social protection landscape have emerged (Waring, Reid, Muherjee \& Shivdas, 2013). There are also commonalities shared by some major players such as World Bank, Asian 
Development Bank, International Labour Organisation and the United Nations Development Progamme). The common thrust is often in relation to social protection as an interventionist and mitigating approach against social and economic risks (ILO, 2006; ADB, 2003; World Bank, 2008; UNDP, 2008). The ADB frames social protection in largely neoliberal terms by suggesting that poverty reduction can be effective by promoting efficient labour markets, diminishing people's exposure to risks and enhancing their capacity to protect themselves against hazards and interruption or loss of income (ADB, 2003). The World Bank also has a neoliberal slant by defining social protection in relation to 'managing social risk' and includes intervention measures to assist individuals, households and communities to enable them to manage risk and develop capacity to support the critically poor (Heltberg, Siegel, Jørgensen 2008).

The market-based approach and the uncritical focus on economic risks such as financial shocks and recession undermine analysis of social risks in relation to gender inequality, domestic violence and social discrimination at the community, social conflict, household and intra-household levels (Holmes \& Jones, 2009). This has prompted the call for a more 'anticipatory' and 'transformative' approach that is gender-responsive and human rights-based (Waring, Reid, Muherjee \& Shivdas, 2013). The assumption here is that social protection must act as a long term fulcrum for social justice and human security. Thus social protection should be understood, not through the philanthropic and charitable lenses where the poor are patronised as 'beneficiaries' of the generosity and social conscience of the market but rather in terms of real social transformation to address inequality and social exclusion created by the market itself.

Understanding the issue of power is an important consideration to gauge the political constraints, power relations, ownership of process, motive of actors, incentives, reasons for implementation and impact on political context (McCord, 2009; Hickey, 2007; Zucco, 2010; Devereux \& White, 2007). In poorer and unstable states where corruption is prevalent and state institutions have limited capacity to deliver, social protection can be an instrument of nation-building to strengthen state legitimacy and developmental reach (Darcy, 2004; Harvey, 2009; Harvey \& Holmes, 2007).

Community-based social protection 'flows from endowment of mutually respecting and trusting relationships' and 'depends on the quality of the set of relationships of a social group' (Szreter, 2009, p. 290). Equally significant is 


\section{'FAILED’ STATES AND THE ENVIRONMENT}

the fact that it is deeply embedded within the local cultures. Community-based coping mechanisms involve daily practices, norms and behavioural trends which people draw from their indigenous cultures, sometimes synthesised with contemporary experiences as the situations demand to adapt to their evolving social environment (Ratuva, 2010).

The global crisis between 2005 and 2009, resulting from the dramatic increase in fuel and food prices and exacerbated by the financial crisis, led to a major rethink of alternative social protection systems by development experts and international aid agencies (McCord, 2009; Davies \& McGregor, 2009; Szreter, 2009; Parks \& Abbott, 2009). As formal and market-based social protection systems failed to cope with the increased demands, many people in the developing world had to fall back on community-based social protection systems for survival.

\section{Quantification of formal social protection}

The method of calculation of the SPI is similar to calculation of the UN's Human Development Index (HDI). Four variables are used: Social Protection Expenditure (SPEXP), Social Protection Coverage (SPCOV), Social Protection Distribution (SPDIST) and Social Protection Impact (SPIMP) (ADB 2008). The formula takes into consideration the formal social protection activities and programmess of public, quasi public and private sector organisations, including Civil Society Organisations and charitable organisations (Baulch, Wood and Weber 2006).

The Pacific country with the highest SPI is Cook Islands with 0.55 and the lowest is Papua New Guinea with 0.01 while in between are Marshall Islands (0.34), Tuvalu (0.26), Fiji (0.15), Tonga (0.08) and Vanuatu (0.08). The Pacific ratings are relatively low compared to more industrialised countries like Japan (0.96) and South Korea (0.76) which have more resources to expand to poverty alleviation (Baulch, Wood \& Weber 2006; Ratuva, 2010).

One of the reasons for Cook Islands high ranking is its special relationship with New Zealand which allows unrestricted mobility between the two countries and the massive flow of capital back to the Cook Islands. This places it as the only Pacific country in the 'above average category' while Nauru, Marshall Islands and Tuvalu are in the 'average' category and Fiji, Tonga, Vanuatu and PNG are in the 'below average' category (Ratuva, 2010, p. 45).

The specific SPI variables differ considerably from country to country 
and on the whole the averages for the Pacific countries are still lower than the overall Asia-Pacific average. For instance the values of SPEXP are much less than SPCOV. On average, Asian and Pacific countries spend 4.8 percent of their GDPs on social protection expenditure (SPEXP) and achieve an overall social protection coverage (SPCOV) level of 35 percent of the seven key target populations. This compares with 4.5 percent and 22 percent respectively for the Pacific Islands. The average proportion of the poor who receive some social protection distribution (SPDIST) benefits is 57 percent, and the social protection programmes (SPIMP) on the poor is 23 percent of those below the poverty line. Still the Pacific Islands figures are low at 35 percent and 11 percent respectively. The reason why the average Pacific values of SPI are low is largely because of the comparatively lesser proportion of urbanisation and impact of the market economy (ILO, 2006). Comparatively, Japan has an SPIMP value of 100 percent.

The problem with the SPI assessment framework is that it only focuses on the formal social protection systems provided by the state, quasi public and private sector institutions, civil society organisations and charitable groups. It does not take into consideration the array of indigenous cultural networks and relationships which act as social safety nets to protect people from the vagaries of social and economic risks. Because these culturally-based systems are not easy to quantify using SPI does not mean that they do not exist.

In some Pacific countries like Vanuatu, Papua New Guinea and Solomon Islands, almost 80 percent of the population live in rural, semi-rural and semi-subsistence life settings and informal means of social protection in the form of cultural support systems are still very much part of their daily lives (Ratuva, 2010). Even those who work in urban areas still maintain their links to their land, traditional culture and identity (ILO, 2006). When the pressure of the market economy increases, people readily fall back on their cultural systems of support to cushion the effects.

It must also be argued that while addressing the causes of poverty and social exclusion is important, any form of intervention must be based on recognising and fulfilling human dignity, rather than on simply fulfilling a humanitarian policy requirement (Mukherjee, et al., 2011). This entails understanding the cultural ethos and world view of poor communities in developing countries who live outside the formal economy and who construct and transform their own world in diverse ways (Barrientos \& Hinojosa- 
Valencia, 2009; Devereux \& Cipryk, 2009; Kohler, Cali \& Stirbu, 2009). The fact that not much attention has been focused on community-based and indigenous social protection despite its importance in addressing the situation of many citizens has led Barrientos \& Hulme (2008) to refer to it as the 'quiet revolution'. This dynamic process takes place outside the realm of the state in an informal context and often provides great potential for community empowerment, control and transformation (Norton, Conway \& Foster, 2001; Shepherd, Marcus \& Barrientos, 2004). Local peculiarities do matter and for some Pacific island states climate change is a growing challenge, and social protection has to be readapted to this as a long-term mitigation strategy (Raworth, 2007; Davies et al., 2008; Heltberg, Siegel \& Jorgensen, 2008).

\section{Pacific community-based social protection}

It is important to state at the outset that community-based social protection systems result from the creative enterprise of synthesising both indigenous and introduced forms of approaches to addressing everyday problems. Local communities construct new modes of adaptation as they try to navigate their way through emerging socio-economic, political and cultural challenges wrought by globalisation. Pacific cultures change and the boundaries and contents are often contested. Contrary to romantic notions of culture as being unchangeable, the notions of kinship, reciprocity, communal obligations, communal labour and land are continually being redefined internally by the local people themselves and externally by outsiders. However, despite their transformation, their critical roles in sustaining the community, although altered in nature by time, remain fundamental.

One of the most resilient mechanisms for social protection in the Pacific is kinship because it provides the basis for collective support for the community's social, economic and psychological needs in times of crisis (Macpherson, 1999). It provides a cultural reservoir for what Bourdieu (1986) refers to as 'cultural capital' (knowledge and skills) that people readily utilise to redress social and economic risks. Response to people's needs in the form of distribution of goods and services is through kinship obligation and ties. Failure to carry out one's kinship obligation is often considered with disdain and seen as contrary to community welfare and spirit.

Kinship is culturally constructed and the boundaries are continually reinforced through socialisation, daily practiCe and historical memory. The boundaries are 
not static but are constantly redefined and extended to determine who the 'insiders' and 'outsiders' are to ensure there is sufficient land and resources for the group. Hauofa (1994) observes that in small Pacific island communities, the kinship boundary transcends the geographical limits and often spans large parts of the ocean, incorporates a number of islands and includes the diaspora as well. The trans-nationalisation of kinship in contemporary Pacific acts as a global social protection system where relatives overseas send remittance back to the islands to help them cope with the everyday economic demands as well as serve their social obligations (Macpherson, 2009; Brown, 2008).

In many Pacific communities kinship relationships articulate both an encompassing collective identity as well as specific links between individuals as expressed in the terms veiwekani in Fiji, au ainga in Samoa, utu in Kiribati and wantok in Vanuatu. These kinship relationships are part of the bigger cultural cosmology represented by terms such as itovo vaka Viti (Fijian way), fa' a Samoa (Samoan way), wantok (Vanuatu way) and te katei ni Kiribati (I-Kiribati way of life).

It is important to emphasise that the significance of kinship does change over time. For some who have developed a more independent life through education, urbanisation, overseas migration and reliance on the market economy the need for kin support may diminish, although kinship may still have significant symbolic value. However, the pressures of poverty and social dislocation in the bourgeoning urban areas such as Suva, Apia, Port Vila and South Tarawa may force people to fall back on their kin for survival. It is common to see three or four nuclear families constituting a household in these urban centres. Of the four countries, Fiji provides the most comprehensive formal social protection system for urban workers but even this is not sufficient to address the prevalence of poverty and other social problems.

In largely rural-based Vanuatu where about 80 percent of the population still live in the subsistence and semi-subsistence sector, kinship as a support mechanism is coming under pressure as a result of rapid urbanisation (Secretariat of the Pacific Community, 2011), growth in tourism and land speculation. Some tribes in Vanuatu, especially in Efate where the capital Port Vila is located, have sold the most valuable portions of their land to foreign speculators and there is not enough land to go around. This has caused tension within tribes and families and there is potential for serious destabilisation in the long run. In Kiribati overpopulation in South Tarawa, where the capital is, has 
created more problems of poverty, depletion of water sources, lack of available land, teenage pregnancy and rise in child custody the $u t u$ has not been able to cope well thus putting a lot of pressure on the state, which does not have any effective formal social protection system in place. The state itself relies on the $u t u$ to provide for social protection given the limited public resources. To make matters worse, competition over scarce land often leads to conflict so social protection and conflict management become closely tied together.

For Samoa where the foreign emigration rate is very high, kinship links become globalised and while this may have weakened links between some family members, it has not significantly weakened people's sense of Samoaness (Macpherson, 2009). One of the ways in which the global kinship link is reinforced is through remittance sent back to relatives in the islands.

Individuals and groups as conscious agents of social transformation are constantly engaging in negotiation with each other and the kinship system and associated social structure in an ongoing dynamic in what Giddens (1986) refers to as structuration. Although in many Pacific communities, individuals may for whatever reasons untie their commitments from kinship obligations, by and large they still need kinship as a cultural prism through which they construct their individual identities as I-Taukei, Samoan, I-Kiribati or Ni-Vanuatu. Those who are seen to lack kinship loyalty are referred to in unsavoury labels such as viavia Kaivalagi in Fiji or fiafia Palagi in Samoa, both referring to 'want to be Europeans'.

The capacity of the kinship system to sustain its social protection role has been undermined by a number of factors such as people being unable to fend for themselves and thus not being able to help those in crisis; families becoming more consumer-oriented and making greater investments in their children, which limits the capacity to support others; and high level of personal debt often to non-institutional moneylenders with very high interest rates, which also reduces their capacity to help.

Moreover, the psychological awareness of being part of a protective and sustaining kinship group provides a sense of security for individuals and families. Given the dominance of Christianity in the four Pacific communities, the notion of social obligation is reinforced by the Christian notion of love. However, the difference between culture-based kinship sharing and Christiantype charity is that the former is seen as a cultural imperative while the latter is often driven by biblical-based notions of giving as a morally righteous 
ideal (Newland, 2009). Nevertheless, despite the dramatically changing circumstances, the kinship system still provides the cushion on which families fall back in times of economic and social risk and this would continue in the foreseeable future.

The second social protection phenomenon is reciprocity which involves exchanging of goods and services to ensure that the community's needs in normal and crisis situations are met. It is voluntary but guided by the norms of kinship obligation. Reciprocity reinforces kinship links and community identity, and defines the boundaries and the types of goods to be produced in a community's exchange economy (Thomas, 1991). In many instances Pacific peoples have readapted it to serve a vital role as a protective cushion to fall back on against poverty and various other negative impacts of the market economy.

One of the most common forms of reciprocity in Fiji is kerekere (literally means to request). This involves families or individuals asking someone within the kin circle for goods (such as food, pig, canoe, house, knife etc) and services (such as building a house, helping in gardening, etc) when the need arises. The idea is that the favour will be reciprocated later not necessarily with the same type or quantity of goods or services but in other forms deemed appropriate at that point in time, depending on the need and availability (Ravuvu, 1987).

The Samoan term o au nei o oe taeao (it's my turn now and the next is yours) expresses the notion of reciprocal relationship well. An important component of this is the practice of totoma which involves asking for mats and even money. Reciprocity can either be formal or informal. Informal reciprocity takes place on a daily basis and may involve food and other commonly used goods. Formal reciprocity is occasional and often involves ceremonies in such things as marriage, funerals and other forms of fa 'alavelave (community and family obligations). Asking and receiving is not considered shameful, although nowadays many younger and more educated individuals may see things differently (Macpherson, 2009).

In Kiribati, the practice of bubuti (which comes from the word butia meaning to request) involves soliciting goods or services from other mwenga (relatives) who are related by blood or adoption within the $u t u$. Refusing a bubuti is considered rude and socially unacceptable. Given the limited access to resources by people (akea aubai) and rising poverty (rongo), compounded by sea-level rise, reliance on bubuti by the i-Kiribati utu may increase in the future rather than diminish. 
The wantok connections in Vanuatu ensure reciprocal exchange takes place within defined tribal and language localities. Often goods exchange takes place either ceremonially or informally and sometimes customary money commodities such as shells and boar tusks are used. As mentioned earlier, the Vanuatu government has embarked on a major cultural project aimed at reviving local social protection systems such as reciprocity as a way of preserving ni-Vanuatu kastam (traditional culture) (Vanuatu Cultural Centre, 2007).

For many urban poor, reciprocity is still important as a social lifeline. Deepening poverty means that many poor families resort to borrowing as a survival measure. Some poor communities in squatter settlements have organised themselves not necessarily based on kinship but on common need as part of their survival network (Barr, 2007; Naidu, Barr \& Seniloli, 2009

One of the most generic forms of cultural ethos is social obligation referring to how individuals and families are bound and guided by kinship norms to provide goods or services when required by a member of the group in a similar way as reciprocity (Macpherson, 1999). Cultural obligation is based on the broader communal ethos of common participation and also involves reciprocal relationship. The common understanding is that there is a cultural contract of sorts between individuals and the collective kin group, such that the problems or needs of an individual are the problems and needs of the entire group, so everything is shared by individuals by virtue of their common collective identity. Individualism is often perceived with disdain (Ravuvu, 1987).

The notion of Fijian oga (burden) and Samoan fa'alavelave (something that bothers you) interestingly have similar connotation. Paradoxically the two terms emphasise that while communal obligation is burdensome and often a subject of derision, it is also recognised as a long term investment. Collectively people share the responsibility of marriages, funerals and other important ceremonies and social occasions, thus taking the pressure off families and individuals who on their own may not be able to cope.

In Kiribati, the practices of te bo (coming together) or te katabetabe (burden) refer to collective sharing of responsibility by members of the $u t u$. Members of the kinship group are obliged to contribute to social occasions (such as feasting during the funeral) and failure to do so may lead to loss of face and social shame. The social protection value of the two practices revolves around the fact that given the limited resources in Kiribati, communal participation ensures that scarce resources are distributed with relative equity 
and the needs of those most at risk are catered for. As a supplementary process, another practice called the te kaonono (food sharing) involves expanding the circulation circle by ensuring that surplus food is shared with people from outside the $u t u$.

In Vanuatu, surplus is often given to guests from other villages and tribes. For instance, on Tana Island the practice of nekowiar or toka involves festivities involving ceremonial activities, dancing, merry-making and gift giving which last for about three days. Gift giving and exchange ensures a constant circulation of food and goods within a locality. In addition the big feasts provide people with the chance to eat together and make up for the often limited daily dietary intake. As in other Pacific communities a feast represents an occasion where people ceremonially share with each other food that one does not normally eat every day such as pork, a highly sought after but rare source of protein.

A significant aspect of communal obligation discussed above is communal labour, a common practice in many Pacific communities. In Fiji and Samoa communal labour involves the entire village taking turns to help build a house or create a new vegetable garden for other families. This is referred to as solesolevaki (to support each other) in Fijian and ala ile pule ole tautua (the path to leadership is service) in Samoan. This practice still exists in some villages in different forms and is no longer practised in urban areas because of the focus on individual labour and immediate reward in the form of wages. The use of communal labour sometimes happens in fishing where villagers would fish together and the catch would be equally shared amongst the families. In Fiji communal labour in the form of collective farming (for taro and kava for instance) is sometimes carried out and the money generated is used for communal projects (Ravuvu, 1987).

Communal labour in Kiribati is mobilised around the notion of karekare (to take turns) and involves economic organisation outside the $u t u$ which provides a system of support for people from different mwenga (household) to lighten the work load. The first type of karekare is te airiri, which consists of women organising their labour for production of items or services for each other such as thatching houses, weaving mats or cooking food. The second type is referred to as the te aiai (sharing fire) where people agree to supply coconut to each other to produce kamwaiwai (toddy syrup, drink and traditional sweetener) one of the main sources of vitamins. Because of the significant 
amount of labour required, kamwaiwai is often produced communally.

In Vanuatu, pulling human resources together to carry out community activities and work (kastem wok) is common in villages. Labour is readily available for those needing support, and often activities such as building a house or canoe and even making someone's food garden are carried out reciprocally. Even in Port Vila where some workers are part of the formal labour market, many still rely on collective labour to subsidise their low income.

\section{Conclusion: Contemporary challenges}

The five aspects of culture-based social protection mentioned are all interrelated and collectively provide resilience and adaptability for the communities concerned. Culture is a living and perpetually evolving and thriving phenomenon and the issue of 'failure' does not arise at all. Proponents of the failed states discourse use variables which are culturally myopic and do not consider the deeper cultural dynamics which shape local people's lives on a daily basis. The selective use of variables reinforces the assumption that some racial groups and societies are more 'superior' than others. For instance, the use of FSI and SPI rankings put Pacific and other post-colonial communities at the lower end of the scale compared to European societies. However, the use of alternative classificatory schemas such as the Happy Planet Index (HPI) reverses the trend with Pacific and post-colonial states communities being ranked towards the top of the list. This is a critical point which the media needs focusing on as a way of revering ideologically crafted myths which denigrate subaltern societies.

Thus the need to understand the dynamics of subaltern communities and their cultural institutions which provide them with resilience is of utmost importance to counter some of the myths propagated by failed states proponents. One way of doing this is to try and fathom the intricacies of local cultures. This article has examined various forms of community-based social protection in the Pacific island communities in the context of the changing dynamics between local culture and the changing global realities. The pressures of inflation, poverty and associated social and economic risks and vulnerabilities compel people to fall back on traditional social protection systems as an economic cushion. In some cases, the adoption of a materialistic and more individualised lifestyle means that traditional obligation is seen as a burden which undermines accumulation. Even those who feel this way are still compelled by social pressure 
to take part in community activities. Sometimes, people consciously engage with both approaches as long as they both serve one's interest sufficiently.

The limited reach of the formal social protection systems in Pacific island communities has compelled a large number of people to resort to indigenous forms of social protection. What differentiates indigenous response mechanisms from formal social protection is the fact that they are an integral component of local social organisation, culture and identity and very much an inseparable part of people's daily life. They are much cheaper, culturally friendly and have the advantage of easy and equal access by members of the community, compared to formal social protection which is only available to a select few who can afford such things as insurance cover. Apart from its capacity to address social and economic risks, it also helps connect people within the kinship system through distribution and sharing. Its reciprocal and distributive characteristic also acts as a conflict resolution mechanism which helps maintain social cohesion and peace within the community.

There is, however, a danger in over-emphasising and even over-romanticising the importance of indigenous social protection systems as the panacea for socio-economic problems for rural Pacific peoples. For some Pacific diaspora and more educated and urbanised people, participation in traditional social protection practices may be self-serving in terms of maintaining a sense of connection and identity. Those with political aspirations may use social protection as a way of mobilising political support for community leadership or parliamentary elections. One's involvement in social protection activities can be driven by both altruistic and self-serving motives and the politicisation of social protection sometimes creates tension within the community. Nevertheless, the peace-building role of community-based social protection can be a powerfully resilient mechanism. These are social realities which are ignored by proponents of the failed state and formal social protection discourses. In championing this critical and alternative approach, the media can play a very significant role in transforming ideas, empowering the subaltern and reversing age-old myths about the primordial superiority of some human beings over others as formal schemas of stratification such as the FSI and SPI suggest. 


\section{‘FAILED’ STATES AND THE ENVIRONMENT}

\section{References}

Arutangai S. (2000). Vanuatu: Overcoming the colonial legacy. Crocombe, R. (Eds.), Land tenure in the Pacific. Suva, UK: Institute of Pacific Studies, University of the South Pacific.

Asian Development Bank. (2003). Social protection strategy. Manila, Philippines: Asian Development Bank.

Ayson R. (2007). The 'arc of instability' and Australia's strategic policy. Australian Journal of International Affairs, 61(2), 215-231.

Barr K. (2007). Squatters in Fiji: The need for an attitudinal change. Suva, Fiji: CCF Housing and Social Exclusion Policy Dialogue Paper (No.1).

Barrientos A, Hulme D. (2008). Social protection for the poor and poorest in developing countries: Reflections on a quiet revolution. Manchester, UK: BWPI Working Paper 30, Brooks World Poverty Institute.

Barrientos A, Hinojosa-Valencia L. (2009). A review of social protection in Latin America. Brighton, UK: Institute of Development Studies.

Bataua B. (1985). Kiribati: A changing atoll culture. Suva, Fiji: Institute of Pacific Studies.

Baulch B., Wood J., \& Weber A. (2006). Developing a social protection index for Asia. Development Policy Review, 24(1), 5-29.

Boege V., Forsyth M. (2007). Customary conflict resolution in a state environment: Cases from Vanuatu. Paper presented to Pacific Islands Political Studies Association, Port Vila, Vanuatu.

Borovnik, M. (2005). Seafarers' 'maritime culture' and the 'i-Kiribati way of life': The formation of flexible identities? Singapore: Journal of Tropical Geography, 26(2), 132-150.

Bourdieu P. (1986). The forms of capital. In J. Richardson (ed.), Handbook of theory and research for the sociology of education (pp. 241-258). New York, NY: Greenwood.

Brown R. (2008). Remittances and development in the Pacific: Effects on human development in Fiji and Tonga. Paper presented to UN Expert Group Meeting on International Migration and Development in Asia and the Pacific, Bangkok, Thailand, 20-21 September.

Cook S., Kabeer N. (2009). Socio-economic security over the life course: A global review of social protection. Brighton, UK: Institute of Development Studies.

Crocombe R. (2000). Land tenure in the Pacific. Suva, Fiji: Institute of Pacific Studies, University of the South Pacific.

Darcy J. (2004). Conflict and social protection: Social protection in situations of violent conflict and its aftermath. London: Theme Paper 5, Overseas Development Institute.

Davies M., \& McGregor A. J. (2009). Social protection responses to the financial crisis: What do we know? Brighton, UK: IDS In Focus Policy Brief, Institute of Development Studies.

Davies M. et al. (2008). Social protection and climate change adaptation. Stockholm, Sweden: Commission on Climate Change. 
Devereux S, Sabates-Wheeler, R. (2004). Transformative social protection. IDS Working Paper 232. Brighton, UK: Institute of Development Studies.

Devereux S, Cipryk R. (2009). Social protection in sub-Saharan Africa: A regional review. Brighton, UK: Institute of Development Studies.

Devereux S., \& White, P. (2007). Pilots, principles or patronage: What makes social protection succeed in southern Africa? Paper prepared for the workshop Social Protection and Ideologies of Welfare in Southern Africa, University of Oxford, 6 December 2007.

Dobell, G. (2007). The arc of instability: The history of an idea. In R. Huisken and M. Thatcher (Eds.), History as policy: Framing the debate on the future of Australian defence. Canberra, Australia: ANU Press.

Giddens, A. (1986). Constitution of society: Outline of the theory of structuration. Los Angeles, Calif.: University of California Press.

Giddens, A. (2001). The third way debate. London, UK: Polity Press.

Gopal, A. (2011, February 22). Lease renewal. The Fiji Times.

Harvey, P. (2009). Social protection in fragile states: Lessons learned, In OECD DAC. Promoting pro-poor growth: Social protection (pp. 183-196). Paris: ECD DAC.

Harvey P., Holmes R. (2007). The potential for joint programs for long-term cash transfers in unstable situations. London, UK: Overseas Development Institute.

Hauofa, E. (1994). Our sea of islands. The Contemporary Pacific, 6(1), 148-161.

Heltberg R, Siegel P B., \& Jorgensen S L. (2008). Climate change, human vulnerability and social risk management. Washington, DC: World Bank.

Hickey S. (2007). Conceptualising the politics of social protection in Africa. Manchester, UK: Brooks World Poverty Institute Working Paper 4, Brooks World Poverty Institute.

Holmes R, \& Jones, N. (2009). Putting the 'social' back into social protection: A framework for understanding the linkages between economic and social risks for poverty reduction. London, UK: ODI Background Notes.

Huffer E, \& Soo A. (2003). Consensus versus dissent: Democracy, pluralism and governance in Samoa. Asia Pacific Viewpoint, 44(3), 281-304.

International Labour Organisation. (2006). Social Security for all men and women: A sourcebook for extending social security coverage in Fiji. Suva, Fiji: International Labour Organisation.

Kamikamica, J. (2000). Fiji-making native land productive. In Crocombe, R. (Ed.). Land tenure in the Pacific (pp. 226-239). Suva, Fiji: Institute of Pacific Studies, University of the South Pacific.

Kohler G., Cali M., \& Stirbu M. (2009). Social protection in South Asia: A review. Kathmandu, Nepal: UNICEF Regional Office for South Asia.

Lambert, B. (2000). Kiribati: Micro-individualism. In Crocombe, R. (Ed.), Land tenure in the Pacific (pp. 164-189). Suva, Fiji: Institute of Pacific Studies, University of the South Pacific.

Lee, H. (2004). All Tongans are connected: Tongan transnationalism. In Lockwood, Victoria (Ed.), Globalisation and culture change in the Pacific Islands (pp. 133148). Upper Saddle River, NJ : Pearson Prentice Hall.

PACIFIC JOURNALISM REVIEW 20 (2) $2014 \mathbf{5 5}$ 


\section{'FAILED’ STATES AND THE ENVIRONMENT}

Lundsgaarde, H.(1978). Post-contact changes in Gilbertese maneaba organisation. In Gunson, N (Ed.), The changing Pacific. Essays in honour of H. E. Maude (pp. 67-79). Melbourne, Australia: Oxford University Press.

Macpherson, C. (2004). Transnationalism and transformation in Samoan society. In Lockwood V (Ed). Globalisation and culture change in the Pacific Islands (pp. 165-181). Upper Saddle River, NJ : Pearson Prentice Hall.

Macpherson, C. (2009). The warm winds of change: Globalisation in contemporary Samoa. Auckland, NZ: University of Auckland Press.

Macpherson, C. (1999). Changing contours of kinship: The impacts of social and economic development on kinship organisation in the South Pacific. Journal of Pacific Studies, 22(2), 71-95.

Maude, H. E. (1977). The evolution of the Gilbertese boti. An ethnohistorical interpretation. Suva: Institute of Pacific Studies and Gilbert Islands, Extension Centre of the University of the South Pacific .

Maude, H. E. (1980). The Gilbertese maneaba. Suva, Fiji: The Institute of Pacific Studies and the Kiribati Extension Centre of the University of the South Pacific .

McCord, A. (2009). Cash transfers and political economy in sub-Saharan Africa. London, UK: Project Briefing No. 31, Overseas Development Institute.

McCord, A. (2009). The global financial crisis: Poverty and social protection, evidence from 10 country case studies. London, UK: ODI Briefing Paper No. 51, Overseas Development Institute.

McCormack, T. (2011). Human security and the separation of security and development. Conflict, Security \& development. 11(2), 235-260.

Mukherjee, A, et al. (2011). Who cares: The economics of dignity. London, UK: Commonwealth Secretariat.

Naidu, V., Barr, K., \& Seniloli, K. (2008). Poverty reduction policies for Fiji. Fijian Studies, 5(2), 293-314.

Nanau, G. (2011). The wantok system as a socio-economic and political network in Melanesia. The Journal of Multicultural Society, 2(1), 31-55.

Newland, L. (2009). Religion and politics: The Christian churches and the 2006 coup in Fiji. In Fraenkel, J., Firth, S. \& Lal, B. (Eds.), The 2006 military takeover in Fiji: A coup to end all coups? Canberra, Australia: ANU E-Press.

Norton, A., Conway, T. \& Foster, M. (2001). Social protection concepts and approaches: Implications for policy and practice in international development. London: Working paper 143, CAPE, Overseas Development Institute.

O’Meara, T., (2000). Samoa: Customary individualism. In Crocombe R. (Ed.), Land tenure in the Pacific (pp. 74-113). Suva, Fiji: Institute of Pacific Studies.

Oduro, A. (2010). Formal and informal social protection in sub-Saharan Africa, Paper prepared for the Workshop Promoting Resilience through Social Protection in Sub-Saharan Africa, organised by the European Report on Development in Dakar, 28-30 June 2010.

Parks, W., \& Abbott, D. (2009). Protecting Pacific Island women and children during economic and food crises. Suva, Fiji: UNDP. 
Ratuva, S. (2010). Back to basics: Towards integrated social protection for vulnerable groups in Vanuatu. Pacific Economic Bulletin, 25(3), 40-63.

Ratuva, S. \& Mead, A. (2007). Pacific genes and life patents: Pacific indigenous experiences and analysis of the commodification and ownership of life. Tokyo, Japan: United Nations University.

Ratuva, S. (2009). Survey on social protection in Fiji. Draft report for Asian Development Bank.

Ravuvu, A. (1987). Fijian ethos: The Fijian way of life. Suva, Fiji: Institute of Pacific Studies.

Raworth, K. (2007). Adapting to climate change: What's needed in poor countries and who should pay. Oxfam: Oxfam International.

Renzio, P. (1999). Women and wantoks: Social capital and group behaviour in Papua New Guinea (WIDER). In Group Behaviour and Development. Helsinki: The United Nations, Helsinki University.

Reilly, B. (2000). 'The Africanisation of the South Pacific.' Australian Journal of International Affairs, 54(3), 261-268.

Sabates-Wheeler R., \& Devereux S. (2007). Social protection for transformation. IDS Bulletin, 38 (3), 23-28.

Said, E. (1977). Orientalism. London, UK: Penguin Books.

Shepherd, A., Marcus, R., Barrientos, A. (2004). Policy paper on social protection. London: UK Department for International Development (DFID) .

Secretariat of the Pacific Community. Population Data base: www.spc.int/sdp/index. php?option $=$ com_docman $\&$ task $=$ cat_view\&gid $=28 \&$ Itemid $=42 \&$ lang $=$ en $\&$ lim itstart $=5$.

Szreter, S. (2009). The new political economy: The importance of social capital. In J. Somavia (Ed.), The global financial crisis and its impact on the work of the global financial system. Geneva, Switzerland: UN System Chief Executives Board for Coordination.

Thomas, N. (1991). Entangled objects: Exchange, material culture, and colonialism in the Pacific. Cambridge, Mas: Harvard University Press.

Tuwere, I. (2002). Vanua: Towards a Fijian theology of place. Suva, Fiji: Institute of Pacific Studies.

United Nations Development Programme (UNDP). (2008). Increasing food prices and food security: Diagnostic issues and policy options. New York, NY: United Nations Development Programme.

Vanuatu Cultural Center (2007). Declared Year of the Traditional Economy, http:// www.vanuatuculture.org/site-bm2/trm/20070207_kastom_ekonomi.shtml. Accessed May 32004.

Wainright, E. (2003). Our Failing Neighbor: Australia and the Future of Solomon Islands. Sydney, Australia: Australian Strategic Policy Institute.

Waring, M., Reid, E., Muherjee, A. \& Shivdas, M. (2013). Anticipatory social protection: Claiming dignity and rights. London: Commonwealth Secretariat.

World Bank (2008). Double jeopardy: Responding to high food and fuel prices. Washington, DC: World Bank. 


\section{'FAILED' STATES AND THE ENVIRONMENT}

Zucco, C. (2010). Cash transfers and voting behavior: An assessment of the political impacts of the Bolsa Familia program. Princeton, NJ: Princeton University.

Dr Steven Ratuva is professor and director of the Macmillan Brown Centre for Pacific Research at the University of Canterbury in New Zealand. He was previously in the Centre of Pacific Studies at the University of Auckland and formerly president of the Pacific Island Political Studies Association (PIPSA). He is a former head of sociology and senior fellow in the Institute of Advanced Studies in Development and Governance, University of the South Pacific, Fiji; and a former fellow in governance at the Australian National University, Canberra.

\section{PACIFIC MEDIA CENTRE}

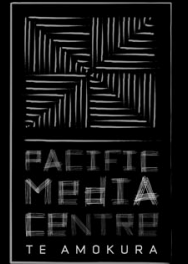

The Pacific Media Centre (Te Amokura) is the only media research and community resource centre of its kind in Aotearoa/New Zealand and has a strategic focus on Māọi, Pasifika and diversity media and community development. It was established by AUT University's Faculty of Design and Creative-Technologies in?007. having evolved from a cluster of research and community collaborations within the School of Communication Studies.

PMC activities include:

- International book and research publication

- Publication of the peer-reviewed Pacific Journalism Reviewresearch journal

- Publication of Pacific Media Centre Online as a media resource and postgraduate outlet

- Publication of Pacific Media Watch, a regional media monitoring service

- Journalism and media research opportunities

- Asia-Pacific internships for postgraduate students

www.pmc.aut.ac.nz I pmc司aut.ac.nz 